Studying Humanitarianism - A Course Audit of Master's Degree Programs in Humanitarian Action ADRIANA A. STIBRAL

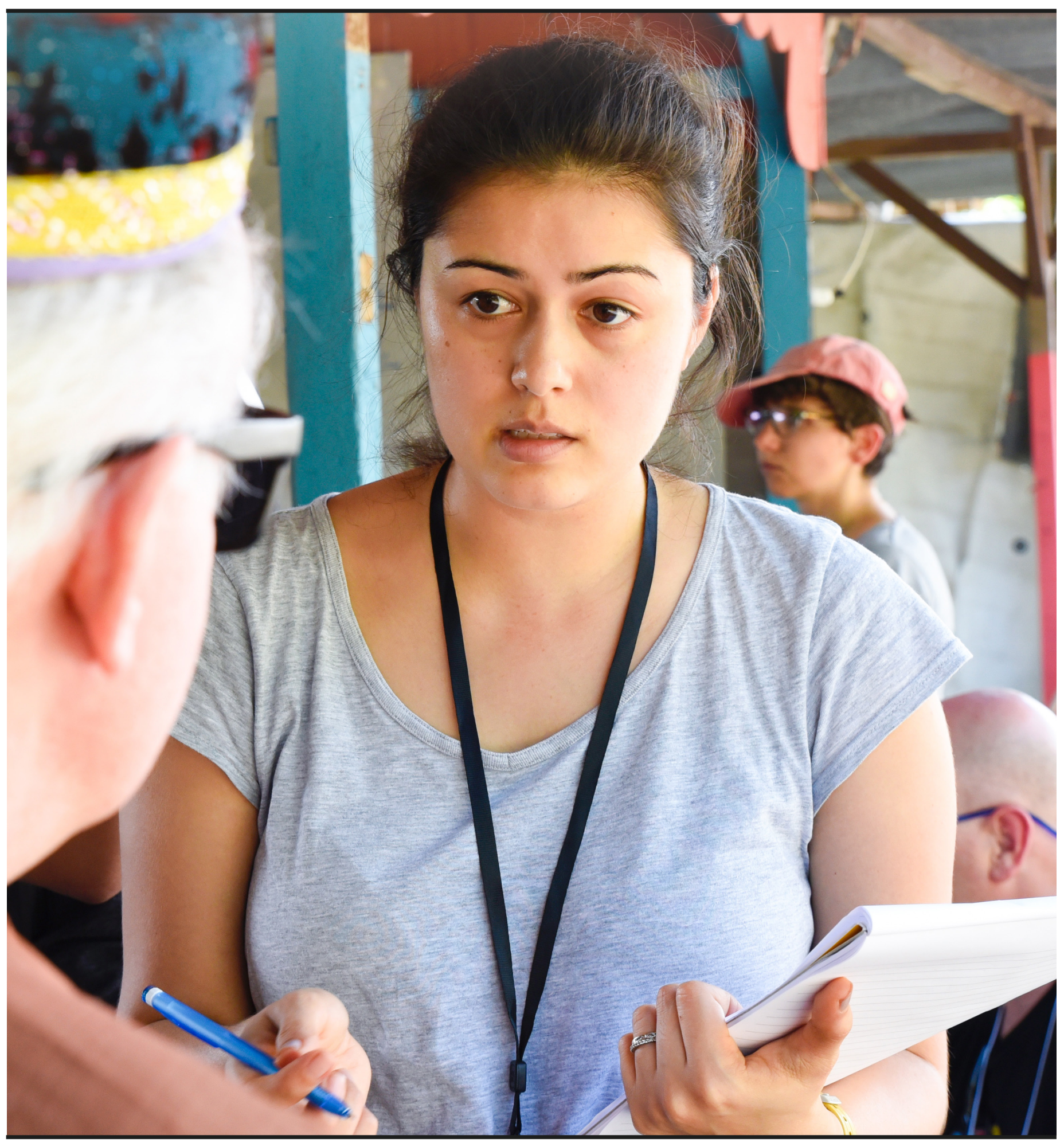




\title{
The Humanitarian Leader: Studying Humanitarianism - A Course Audit of Master's Degree Programs in Humanitarian Action
}

\author{
ADRIANA A. STIBRAL
}

FEBRUARY 2021

\begin{abstract}
ABOUT
Adriana A. Stibral is a casual academic staff member at Deakin University, where she is also completing her PhD. Her doctorate examines the contribution of the emerging 'Humanitarian Studies' field of scholarship to the professionalisation and transformation of the humanitarian sector. Stibral is an Associate Humanitarian Trainer for RedR Australia, a leading international humanitarian response agency that trains and deploys technical specialists. Previously, she was employed as a university lecturer and course director in the field of Humanitarian and Community Studies. Regions where Stibral has worked include Europe, Australia, the United States, West Africa and the Middle East.
\end{abstract}

\section{ACKNOWLEDGMENTS}

The author would like to thank Deakin University, Professor Dr Matthew Clarke and Dr Nazanin Zadeh-Cummings for the opportunity to undertake this research project.

The views expressed in this report are those of the author and do not necessarily reflect the views of the Centre for Humanitarian Leadership.

\section{The Centre For Humanitarian Leadership \\ Deakin University \\ 1 Gheringhap Street \\ Geelong, Victoria 3220}

\section{COPYRIGHT}

This paper was prepared for the Centre for Humanitarian Leadership.

The views expressed herein are those of the authors and do not necessarily reflect the views of the Centre for Humanitarian Leadership. These papers are circulated for discussion and comment purposes. They have not been peer reviewed.

(C) 2021 Adriana A. Stibral. All rights reserved. 


\section{Abstract}

Humanitarian emergencies are increasing globally and the world is facing the worst human displacement crisis since the end of World War II. The number of forcibly displaced people due to conflict, violence, severe weather events and complex emergencies has reached a record high of approximately 70 million. The United Nations estimates that 235 million people will urgently require humanitarian assistance in 2021 at a cost of approximately US\$35 billion. The increase of emergencies as well as the expansion of the humanitarian sector are accompanied by growing levels of professionalisation. The past few decades are characterised by humanitarian reforms, and the emergence of new codes, standards and frameworks to provide improved, better coordinated humanitarian aid. The increasing professionalisation of humanitarian aid is also reflected in the rapid growth of professional training and formal education. University courses in the field of 'humanitarian action' are multiplying around the globe. This is especially the case at a master's level and most visible in the 'Global North'. Despite this trend, there is no universal agreement on a core course curriculum in Humanitarian Studies. This working paper surveys 23 'humanitarian action' master's degree programs offered in the US, the UK, Europe, Australia and Nigeria to identify key commonalities across courses. This paper does not put forth a proposal of how a core curriculum should look like; rather, it highlights core commonalities across programs. Findings presented in this working paper are preliminary and contribute to the understanding of what could qualify as part of a 'core curriculum'. 


\section{INTRODUCTION}

Humanitarian emergencies are increasing globally and the world is facing the worst human displacement crisis since the end of World War II. The number of forcibly displaced people due to persecution, conflict, violence, severe weather events, war, protracted crises and complex emergencies reached a record high of approximately 70 million in 2019 (UNHCR 2019). The United Nations Office for the Coordination of Humanitarian Affairs (OCHA) estimates that 235 million people will urgently require humanitarian assistance in 2021, necessitating a total of US\$35 billion to meet the needs of disaster-affected populations (OCHA 2020).

Humanitarian aid and the humanitarian sector have undergone large-scale change over the past few decades, in particular, since the 1990s. Profound failures to deliver humanitarian assistance in a well-coordinated, transparent, professional and efficient way have led to significant humanitarian reforms and paradigm shifts. New ways of working, new frameworks, codes, principles and standards have emerged (Good Humanitarian Donorship (GHD) 2016; James 2016). They include the introduction of the minimum standards in humanitarian response-also known as Sphere Standards-in 2000, followed by the 2012 developed Core Humanitarian Competencies Framework (Sphere Project 2011; Consortium of British Humanitarian Agencies (CBHA) 2012; Sphere Project 2018).

The humanitarian sector is growing financially, involves a great number of traditional and new actors, and is becoming increasingly complex (Walker \& Maxwell 2009; Maxwell \& Gelsdorf 2019). The need for professional humanitarian practitioners is greater than ever before. Sudden, slow-onset and complex disasters require rapid and efficient aid responses, mobilising local, national, regional and international resources and personnel. The number of humanitarian and development aid workers is increasing by approximately 6\% annually (Active Learning Network for Accountability and Performance in Humanitarian Action (ALNAP) 2010). An estimated 570,000 field personnel work in the humanitarian sector, with growing numbers of local/national humanitarian staff and a decline in international (expatriate) staff (ALNAP 2018).

Humanitarian agencies are increasingly changing their hiring practices. Employing untrained, inexperienced or unqualified volunteers has become unsustainable. Today's humanitarian professional must have technical skills, have undertaken formal training and educationoften at a postgraduate level-and have professional experience. A master's qualification is often an entry requirement for working in the humanitarian sector or filling specific senior-level positions. The majority of humanitarian employment opportunities advertised internationally through OCHA's humanitarian information service ReliefWeb clearly specifies that job applicants must hold a university degree, often at a master's level (ReliefWeb 2020).
The ongoing professionalisation of humanitarian aid and the sector is also clearly reflected in and accompanied by the rapid expansion of educational initiatives around the world. These include formal humanitarian training, short courses and higher education programs. In particular, there is a growth in academic postgraduate master-level courses in the field of Humanitarian Assistance, Humanitarian Action and Humanitarian Studies. The majority of postgraduate courses in the field of Humanitarian Studies and in allied fields-such as Emergency and Disaster Management-have only emerged over the past 20 years. They are predominantly offered in the 'Global North', including the United States of America (US), Canada, the United Kingdom (UK), Europe, Australia and New Zealand (Rainhorn, Smailbegovic \& Jiekak 2010; Johnson et al. 2013).

Despite this trend, there is no agreement on a core course curriculum in Humanitarian Studies. This working paper surveys 23 'Humanitarian Action/ Studies' master's degree programs offered in the US, the UK, Europe, Australia and Nigeria to identify key commonalities across courses. This paper does not put forth a proposal of how a core curriculum should look like; rather, it highlights core commonalities and differences across programs. Findings presented in this working paper are preliminary and contribute to the understanding of what could qualify as part of a 'core curriculum'. Findings are also relevant for stakeholders involved in current and future curriculum development and re-design activities.

\section{SCOPE OF THE COURSE AUDIT AND METHODOLOGY APPLIED IN THE SURVEY}

The scope of the course audit and predetermined factors for selecting and analysing Humanitarian Action master's degree programs included:

- Master-level courses (including Master of Arts and Master of Science)

- 'Humanitarian Assistance/Aid/Action/Studies' included in the course title

- Curriculum content that focuses on humanitarian assistance/aid/action

- Anglophone courses only (or courses where the language spoken and written is predominantly English).

The strategy applied to collect data for the course audit included the following activities:

- Reviewing existing key literature on humanitarian assistance and humanitarian studies related to postgraduate master-level programs

- Using the Google search engine to identify programs. Search terms (one word per entry and a combination of words per entry) included 'humanitarian', 'humanitarian studies, 'humanitarian action/ assistance/aid', 'postgraduate', 'master(s)', 'studies', 'program', 'university', 'higher education', 'emergency', 'disaster, 'development' 
- Using 'Find a University Ltd', 'Graduate Prospects Ltd' and 'Studyportals Masters' search engines/websites to identify programs

- Accessing university homepages and other programrelated websites

- Accessing other publically available course-related information, brochures, flyers, and program materials.

Overall, data on 23 master's degree programs was collected as part of this particular course audit. The courses included in the data pool have been selected based on the course title, core topics, subjects and themes covered in the curriculum. Any kind of master's degrees, including Master of Science (MSc) and Master of Arts (MA), are included in the data pool. Master's programs that include additional topic foci (both in the title as well as in their course curricula) are also included in the data pool on condition that 'humanitarian assistance/humanitarianism' represents a core theme in the master's program.

Programs that cover some humanitarian aid-related aspects but have different course titles and different thematic foci (for example, Sustainable Development, Refugee [and Forced Migration] Studies, Peace and Conflict Studies, Emergency and Disaster Management et cetera) are excluded from the data pool. Disciplinespecific courses (for example, Public Health, Law, Engineering and Medicine) that have humanitarian specialisations (for example, humanitarian engineering and humanitarian logistics) are also excluded. Finally, short courses, professional certifications, formal training, undergraduate programs, bachelor's specialisation and other postgraduate programs, such as graduate certificates, graduate diplomas, and diplomas, are also excluded.

Based on the outlined selection criteria, the 23 Humanitarian Action/Assistance/Studies master's programs and universities included in this survey are:

1. University of London, London, UK: MSc Humanitarian Action

2. United Nations Institute for Training and Research (UNITAR), Geneva, Switzerland and Oxford Brooks University, Oxford, UK: MA in Humanitarian Action and Peacebuilding

3. University of Bath, Bath, UK: MSc Humanitarianism, Conflict and Development

4. London School of Economics (LSE) and Political Science, London, UK: MSc International Development and Humanitarian Emergencies

5. University of Manchester, Manchester, UK: MSc Humanitarian Practice

6. University of York, York, UK: MSc International Humanitarian Affairs

7. Brunel University, London, UK: MSc Anthropology of International Development and Humanitarian Assistance

8. Liverpool School of Tropical Medicine, Liverpool, UK: MSc Humanitarian Studies
9. Network on Humanitarian Action (NOHA) - includes core curricula from all partner universities: Erasmus Mundus Joint Masters Programme in International Humanitarian Action

10. Universidade Fernando Pessoa, Portugal: Master in Humanitarian Action, Cooperation and Development

11. Sciences Po, France: MA in Human Rights and Humanitarian Action

12. Geneva Centre of Humanitarian Studies, Geneva, Switzerland: Master of Advanced Studies in Humanitarian Action

13. School of International Training, Washington, US: MA Humanitarian Assistance and Crisis Management

14. Fordham University, New York, US: MSc Humanitarian Studies

15. Fordham University, New York, US: MA in International Humanitarian Action

16. Feinstein International Center, Tufts University, Boston, US: MA in Humanitarian Assistance

17. Wheaton College Graduate School, Wheaton, US: MA Humanitarian and Disaster Leadership

18. Jesuit Universities Humanitarian Action Network (JUHAN), US: Master of Professional Studies in Humanitarian Service Administration

19. Deakin University, Melbourne, Australia: Master of Humanitarian Assistance

20. Deakin University, Melbourne, Australia: Master of Sustainable Development and Humanitarian Action

21. Western Sydney University, Sydney, Australia: Master of Humanitarian and Development Studies

22. University of Maiduguri, Centre for Peace, Diplomatic and Development Studies, Nigeria: Masters of Humanitarian and Refugee Studies

23. University of Ibadan, Nigeria: Professional Master of Humanitarian and Refugee Studies.

To identify central characteristics and commonalities of all 23 Humanitarian Action master's programs, the data on each program was collected disaggregated by the following categories:

- University/institution's name

- Department and/or faculty/school

- Program/course name

- Country

- Length of the program

- Total number of units/credit points

- Compulsory units/subjects

- Elective units/subjects

- Cost

- Delivery mode

- Research component

- Internship requirement

- Entry requirements

- Notable characteristics

- Available scholarships.

Key data was entered into an Excel spreadsheet. (The document is not attached to this working paper, but available upon request). The spreadsheet was used as the foundation for the basic comparison of the data. There are some limitations to using this approach. They include a lack of quantitative and qualitative 
data retrieved from interviews, surveys, focus group discussions with course directors, lecturers, students and graduates. Additionally, more in-depth data collection and data analysis of the following aspects has not been undertaken as part of this survey: student feedback, employability upon course completion, university-industry partnerships, university rankings, academic staff's background, teaching pedagogies, teaching materials, assessment requirements, unit learning objectives and course learning outcomes.

However, as the focus of this Humanitarian Action master's course audit focuses solely on the course structure and central course components, including key subjects and themes that form part of the curriculum, the available data is sufficient for the inquiry.

\section{FINDINGS}

The initial online search for humanitarian assistancerelated master's degree programs through various websites, including 'Find a University Ltd', 'Graduate Prospects Ltd' and 'Studyportals Masters', resulted in a listing of 387 programs offered around the world. Broken down by continent, 276 programs appeared for Europe, 67 for North America, 33 for Oceania, 12 for Asia, five for Africa, and one for South America (Studyportals Masters 2020).

Closer examination of those 387 programs showed that a large number of listed programs are not mainly humanitarian aid-focused and/or titled, but include master's degrees termed as Humanitarian Engineering, Development Studies, Humanitarian Health Management, International Humanitarian Law and Human Rights, Humanitarian Logistics, Risk and Disaster Science, Disaster Management, Peacebuilding and Law, among others. These and similarly titled master's courses were not included in the selection of key Humanitarian Action/Studies master's degree programs as per the aforementioned set out key selection criteria for this specific course audit. Courses that included 'humanitarian studies/action/humanitarianism' and another term (for example, 'development') in their titlefor instance, Master of Development and Humanitarian Action-were included in the list of courses under the condition that 'humanitarian/humanitarianism' appeared in the program title and presented a curriculum focus. This left a total of 23 master's courses that were included in the review and analysis for this survey. All courses except two (Masters of Humanitarian and Refugee Studies offered by the University of Maiduguri in Nigeria and Professional Master of Humanitarian and Refugee Studies offered by the University of Ibadan in Nigeria) are delivered by institutions located in the 'Global North'.

The author acknowledges that humanitarian aid-related topics, themes and specialisations are also covered by other postgraduate programs that do not meet the aforementioned pre-determined course inclusion criteria for this particular course audit. Examples include non-humanitarian titled and focused programs such as Peace and Conflict Studies, International Human Rights/Humanitarian Law, International Relations/ Studies, Refugee and Forced Migration Studies, Disaster Management and Sustainable Development. Countries outside the 'Global North' offering such programs include South Africa, Egypt, United Arab Emirates, Colombia, Pakistan, India, Bangladesh, Occupied Palestinian Territory, Malaysia, Thailand, China and Vietnam (Find A University Ltd. 2020; Studyportals Masters 2020). Notably, postgraduate courses in Disaster Management are increasingly offered throughout Asia and SouthEast Asia. Programs in Sustainable Development are increasingly offered by universities located in the Middle East. However, those programs are often technical and discipline-specific.

For the purpose of this Humanitarian Assistance master's course audit, only those programs that met all predetermined selection criteria were included. The analysis of all 23 courses based on the aforementioned categories showed that several main themes emerged across the data: course entry requirements, flexibility, research, practical components and academic foci (core themes in the curriculum and subjects taught).

\section{KEY COMMONALITIES AND SIMILARITIES ACROSS MASTER'S DEGREE PROGRAMS}

Course entry requirements are similar across all Humanitarian Action master's courses: the successful completion of an undergraduate degree in the same or similar field; a formal application that includes a curriculum vitae, a letter of motivation and/or letters of references in some universities; and an IELTS test score of 6.5 (in some cases, 7.0) is required where English is not the applicant's native language. Seventeen out of 23 programs included a specific IELTS test score requirement or equivalent. Seven out of 23 programs either mentioned that professional experience is preferable and/or permits applicants without a bachelor's degree to be considered for selection into the program if they hold two to five years' relevant professional experience. Nine out of 23 programs did not mention the relevance or need for previous practical experience. A strict requirement of having two to five years' of professional experience in the humanitarian sector in order to successfully apply for course entry was the case for the remaining seven out of the analysed 23 programs.

Flexibility is a major aspect of all 23 Humanitarian Action master's courses. Categories of flexibility include the length of the program, delivery mode and location. The majority of courses are either one or two years (full-time). Nearly all programs offer flexibility in studying part-time, full-time or a combination of both. This, in turn, impacts the length of the program, depending on the modality of study a student chooses. Various programs also included options to complete intensives, including overseas. Four out of 23 Humanitarian Action master's degree programs are delivered exclusively online (University of London, 
Oxford Brooks University, Deakin University, University of York). This allows students to study from anywhere in the world, so long as they have access to the internet. Six other master's programs are seemingly offered only on-campus (London School of Economics, University of Maiduguri, University of Ibadan, Science Po, Fordham University and Tufts University). The remaining 13 programs are delivered in a blended format (online and on-campus)-many of which include a residential or overseas intensive component (for example, University of Bath, Manchester University, Brunel University, NOHA program, Fordham University, School of International Training). The modality of studying is connected to location flexibility. Multiple programs show flexibility in locations where students attend classes and complete other course requirements such as research, fieldwork, placements and internships. For example, the NOHA program is offered by eight European universities and allows students to choose the desired location for their compulsory semester abroad at one of NOHA's partner universities.

Research is a core requirement for all Humanitarian Action master's programs except two (two universities did not provide information on required or optional research components). The majority of programs (fourteen) require students to complete a master's dissertation/thesis. Where a dissertation is not required, students must complete a research-related capstone, undertake a research project, and/or submit a research paper as part of the program (seven). Universities that did not specifically mention a dissertation or thesis but other forms of research include Tufts University, Western Sydney University, Deakin University, School of International Training and the University of Ibadan. The majority of programs also embed compulsory researchrelated seminars, capstone units, workshops or certain subjects (for example, Research Methods, Research and Ethics, Research Project).

Practical components are optional or compulsory in approximately half of the 23 Humanitarian Action master's programs. Fifteen programs have no mandatory practice requirement in their curriculum. In eight out of 23 Humanitarian Action master's programs, a practical component in form of a placement, internship, training, simulation-based learning or fieldwork is a mandatory requirement for course completion. Practical components vary across universities with regard to the type of practice-based learning. For example, the NOHA program requires students to undertake 'regional training' at a partner university and complete an internship placement. Western Sydney University and Sciences Po require students to complete either an internship or overseas study exchange. The School of International Training embeds a mandatory field practicum in Jordan, Switzerland or Uganda. Wheaton College Graduate School immerses students in fieldwork, a placement, and a simulation-based field operations subject. The University of Maiduguri and the University of Ibadan encourage students to complete their compulsory internship in a refugee or internally displaced people (IDP) camp in Africa. Where a professional practice component is not a mandatory requirement, students usually are provided with the opportunity to complete fieldwork or a placement as an elective.

Academic foci, themes and subject areas that Humanitarian Action master's programs cover in their curricula (to a varying extent) include history of humanitarianism, humanitarian principles and frameworks, aid in theory and practice, key issues in humanitarian (and development) practice, and critique of humanitarian aid practice (not part of or across all programs). In addition, conflict and security, peacebuilding, international development/ development aid, sustainable development, politics/ global governance, global/public health, human rights, forced migration, refugees, displacement, politics and globalisation, reconstruction and re-building also form part of the curriculum. Finally, program foci also include technical sectors in humanitarian response, media, advocacy and communication, geographic concentrations, leadership, teamwork, self-management, fundamentals of research, research dissertation, placement/practicum, training and fieldwork.

\section{Common themes, subject areas, research and practical} components that are comprehensively integrated by the majority of all 23 analysed master's degree programs in their curricula and, thus, could qualify as common principal curriculum components, are listed in the table below. 
Dissertation/thesis and/or other

research component
22

17

History of humanitarianism and the

humanitarian system-principles,

frameworks, ethics, cutting issues in

development and aid practice

(critique of humanitarianism)

\begin{tabular}{|c|c|c|}
\hline Internship/placement/practicum & 8 & 3 \\
\hline $\begin{array}{l}\text { Development/Development Studies and/ } \\
\text { or Sustainable Development }\end{array}$ & 7 & 4 \\
\hline Disaster and emergency management & 7 & 2 \\
\hline $\begin{array}{l}\text { Global Governance, international } \\
\text { relations (IR), world politics, complex } \\
\text { humanitarian emergencies, the political } \\
\text { economy of aid }\end{array}$ & 6 & 6 \\
\hline Management & 6 & 2 \\
\hline $\begin{array}{l}\text { Conflict, conflict resolution, peace and } \\
\text { peacebuilding }\end{array}$ & 5 & 4 \\
\hline $\begin{array}{l}\text { Protection and International } \\
\text { Humanitarian Law (IHL) }\end{array}$ & 5 & 2 \\
\hline Leadership, self-management, teamwork & 5 & 1 \\
\hline Global/public health & 4 & 6 \\
\hline $\begin{array}{l}\text { Technical/sector-related aspects of } \\
\text { humanitarian response }\end{array}$ & 4 & 1 \\
\hline Forced migration/refugees/IDPs & 4 & 1 \\
\hline Negotiation and diplomacy & 3 & 4 \\
\hline Media, advocacy and communication & 3 & 4 \\
\hline Human rights & 3 & 4 \\
\hline $\begin{array}{l}\text { Gender/feminism/gender-based } \\
\text { violence (GBV) }\end{array}$ & 3 & 2 \\
\hline
\end{tabular}

Figure 1: Core themes, topics and subject areas in Humanitarian Action master's programs (table created by author based on data collection and analysis) 
Evidence shows that nearly all Humanitarian Action/ Studies master's programs include a research component in their curriculum. Another core element is the teaching and learning about the history of humanitarianism and humanitarian assistance, humanitarian ethics, principles and frameworks, as well as cutting issues faced by the sector and humanitarian practitioners. A professional practice component in form of a placement, internship, training and/or fieldwork is also a key component in the curriculum in about half of all analysed programs. Other widely shared curriculum teaching and learning contents comprise emergency and disaster management, the international system (global governance/international relations, political aspects/political economy of aid), (sustainable) development, conflict/conflict resolution and peace (building). Other thematic areas that are part of at least a quarter of all analysed master's programs include management, leadership, protection/ International Humanitarian Law (IHL), (global/public) health, and forced migration/refugees/IDPs. Only a small number of programs (5-7) embed subjects around negotiation/diplomacy, media and advocacy, human rights and gender/gender-based violence (GBV) in their repertoire of core or elective units.

\section{KEY DIFFERENCES ACROSS MASTER'S DEGREE PROGRAMS}

Some programs have specific academic foci. Some courses place an emphasis on technical or other predominantly humanitarian sector-related aspects linked to humanitarian action. This emphasis applies mainly to the selection of elective modules and subjects that students can choose from, but may also include compulsory/core subjects. Those, for example, include food security/food and nutrition in emergencies (for example, University of York, University of London, JUHAN, Deakin University and Tufts University), climate change (University of London, University of Manchester, Liverpool School of Tropical Medicine and Geneva Centre of Humanitarian Studies) or logistics and supply management (Liverpool School of Tropical Medicine and Fordham University). Emerging non-traditional themes and subject areas that some programs offer as elective or core units also include anthropology (University of Manchester, Brunel University, NOHA and Sciences Po), human(itarian) resources planning and administration (University of Manchester, Fordham University and JUHAN).

Other identified differences in the analysed 23 Humanitarian Action master's programs include a varying level of interdisciplinarity. Some programs stressed the importance of interdisciplinary teaching and research, whereas other programs had a quite discipline-specific focus (for example, development studies, peace and conflict studies, security studies, social sciences, psychology, health, disaster studies and anthropology). Humanitarian Action programs are housed in various departments, faculties and schools. They include Health Science, Law and Political Science, International Relations, Human Rights and, Theology.
Furthermore, programs offered by universities in the US, the UK and Australia notably offered various exit options for students who decide not to complete the entire master's program. Options include graduate diplomas, graduate certificates, postgraduate diplomas and postgraduate certificates. Some programs target a broader-level audience, while other programs are specifically aimed at practitioners already working in the humanitarian aid sector.

\section{DISCUSSION AND CONCLUSION}

23 Humanitarian Action master's programs from around the world were analysed as part of this specific course audit. The predetermined factors for selecting and analysing humanitarian postgraduate programs included master-level courses, 'Humanitarian Assistance/Action/ Aid/Studies' included in the course title, curriculum focus on humanitarian action, and Anglophone courses only. Based on those course inclusion criteria, the search resulted in 23 Humanitarian Action master's programs. All programs are offered by academic institutions located in the 'Global North' (for example, the US, the UK, Europe and Australia), except two programs that are offered by universities in the 'Global South' (Nigeria)).

A plethora of institutions in the 'Global North' as well as the 'Global South' offer master-level programs in humanitarian aid-related fields (for example, emergency and disaster management, (sustainable) development, and peace and conflict studies). However, those programs are not specifically titled as 'humanitarian'. Moreover, they are often technical and disciplinespecific programs (for example, engineering, public health and international law).

The data analysis materialised that key commonalities of all 23 Humanitarian Action master's programs included in this survey comprise course entry requirements, flexibility, research, practical components and, curriculum-related academic foci.

Acknowledging the diversity within and between different humanitarian master's degrees and in which institution's departments, schools and faculties they are housed, there is much room for differences in approach and in the belief of what constitutes 'core' or 'common' concepts.

There are a number of key themes, topics and subject areas across all Humanitarian Action master's programs that could be considered as part of a common core curriculum. They comprise a research and/or dissertation element; a mandatory or optional practical component in form of training; a placement/internship; an intensive/workshop; and overseas mobility and/or fieldwork. Another core area in the teaching curriculum is the learning about and analysis of the humanitarian system, including the history of humanitarianism, humanitarian principles, frameworks, ethics and cutting issues in theory and practice. This is followed by the teaching, learning and research in the field of emergency and disaster management, the international system 
(global governance/international relations, political economy of aid), (sustainable) development, conflict/ conflict resolution and peace (building). Lastly, at least one quarter of all analysed master's degrees include aspects of leadership, management, protection/IHL and (public) health, as well as refugee/IDP/forced migrationrelated topics into the curriculum. In the process of the data analysis, it surfaced that only a handful of programs embed compulsory or elective subjects on negotiation/ diplomacy, media and advocacy, human rights and GBV/ gender-related issues of humanitarian aid into the curriculum. A critical examination of humanitarian aid and holistic critique of the entire humanitarian sector seem to only be an emerging phenomenon in course curricula. This illustrates that Humanitarian Action master's programs are still in the process of evolving.

This course audit proves the increasing emergence of common core themes, topics and subjects across Humanitarian Action master's programs. This investigation also unveils that a number of programs differ with regard to program duration, delivery mode as well as (optional) specialisations and thematic foci.
Further research is required to answer the question of how an internationally agreed Humanitarian Action master's degree core curriculum could-or should-be designed so that it meets industry demands and prepares current and prospective humanitarians for professional practice. Future research could entail the comparison and analysis of Humanitarian Action master's course learning outcomes, core units/subjects, assessment strategies, teaching and learning pedagogies, staff composition, university-industry partnerships, student satisfaction and graduate's employability upon course completion. Finally, an analysis of humanitarian actionrelated programs around the globe is essential to include the voices and views of all regions around the world in the design of an agreed common curriculum for Humanitarian Action master's degree programs. 


\section{REFERENCES}

ALNAP (Active Learning Network for Accountability and Performance in Humanitarian Action) 2010, The State of the Humanitarian System. ALNAP Study, ALNAP/ODI (Overseas Development Institute), London.

ALNAP (Active Learning Network for Accountability and Performance in Humanitarian Action) 2018, The State of the Humanitarian System. ALNAP Study, ALNAP/ODI (Overseas Development Institute), London.

CBHA (Consortium of British Humanitarian Agencies) 2012, Core Humanitarian Competencies Framework, retrieved from https://www.alnap.org/help-library/core-humanitarian-competencies-framework

Find A University Ltd. 2020, Find a masters, retrieved from www.findamasters.com

GHD (Good Humanitarian Donorship) 2016, About GHD, retrieved from: https://www.ghdinitiative.org/ghd/gns/aboutus/about-ghd.html

Graduate Prospects Ltd. 2020, Prospects. Find a postgraduate course, retrieved from https://www.prospects.ac.uk

James E 2016, 'The professional humanitarian and the downsides of professionalisation', Disasters, 40(2):185-206, doi:10.1111/disa.12140

Johnson K, Idzerda L, Baras R, Camburn J, Hein K, Walker P and Burkle FM 2013, 'Competency-based standardized training for humanitarian providers: making humanitarian assistance a professional discipline', Disaster medicine and public health preparedness, 7(4):369-372, doi:10.1017/dmp.2013.10

Maxwell D and Gelsdorf K 2019, Understanding the humanitarian world, Routledge, New York.

OCHA (United Nations Office for the Coordination of Humanitarian Affairs) 2020, Global humanitarian overview 2021, retrieved from https://reliefweb.int/sites/reliefweb.int/files/resources/GHO2O21_EN.pdf

Rainhorn JD Smailbegovic A and Jiekak S 2010, University training and education in humanitarian action, Geneva Center for Education and Research in Humanitarian Action, Geneva.

ReliefWeb 2020, Jobs, retrieved from https://reliefweb.int/jobs

Studyportals Masters 2020, Never stop learning. Discover thousands of Master's degrees worldwide, retrieved from www. mastersportal.com

Sphere Project 2011, Sphere Handbook: Humanitarian Charter and Minimum Standards in Humanitarian Response, 3rd ed., Practical Action Publishing, Rugby.

Sphere Project 2018, Sphere handbook: Humanitarian Charter and Minimum Standards in Humanitarian Response, 4th ed., Practical Action Publishing, Rugby.

UNHCR (The Office of the United Nations High Commissioner for Refugees) 2019, Figures at a Glance, retrieved from https://www.unhcr.org/en-au/figures-at-a-glance.html

Walker P Maxwell DG 2009, Shaping the humanitarian world, Routledge, New York. 